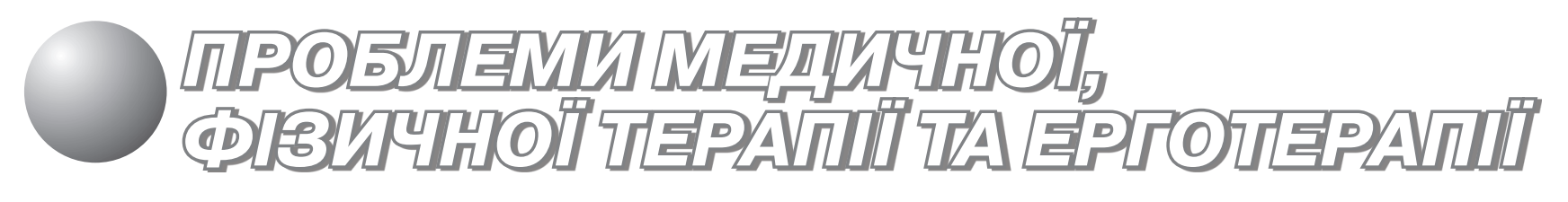

DOI: https://doi.org/10.32652/spmed.2021.2.78-83

\title{
Вплив кардіореабілітації із застосуванням телемедичних технологій на якість життя осіб, хворих на ішемічну хворобу серця
}

\author{
УДК 616.127-005.8+616.12-005.4:621.391.3 \\ М. С. Балаж, В. П. Костенко
}

Національний університет фізичного виховання і спорту України, Київ, Україна

\begin{abstract}
Резюме. Мета. Оцінити вплив запропонованої реабілітаційної програми із застосуванням фізичних тренувань, що ґрунтується на використанні телемедичних технологій, на якість життя хворих на стабільну ішемічну хворобу серця. Методи. Аналіз медичної документації, статистична обробка даних. Результати. Застосування реабілітаційних заходів сприяло статистично значущому $(\mathrm{p}<0,05)$ покращенню якості життя у пацієнтів групи втручання та групи порівняння. Найбільш суттєву позитивну динаміку спостерігали за шкалами «Рольове функціонування», «Загальне здоров'я» та «Емоційне функціонування». При цьому не було виявлено статистично значущої різниці між групою втручання та групою порівняння за всіма показниками якості життя, отриманими при повторному опитуванні пацієнтів. Амбулаторна програма кардіореабілітації із застосуванням телемедичних технологій продемонструвала позитивний вплив на якість життя хворих на стабільну ішемічну хворобу серця, порівнюваний з ефектом програми, реалізованої на базі центру. Під впливом реабілітаційної програми у групі втручання та групі порівняння спостерігали суттєву позитивну динаміку показників, що характеризують як фізичний, так і психічний компоненти здоров'я, тоді як у групі порівняння статистично значущих змін за всіма показниками якості життя виявлено не було.
\end{abstract}

Ключові слова: телекардіореабілітація, фізична терапія, ішемічна хвороба серця, якість життя.

\begin{abstract}
Effects of cardiac rehabilitation with the use of telemedicine technologies on the quality of life of people with coronary heart disease
\end{abstract}

M. S. Balazh, V. P. Kostenko

National University of Physical Education and Sport of Ukraine, Kyiv, Ukraine

Abstract. Objective. The study was aimed at assessing the impact of the developed rehabilitation program using physical exercise, which was based on the use of telemedicine technologies, on the quality of life of patients with stable coronary heart disease. Methods. Analysis of medical documentation, statistical data processing. Results. The use of rehabilitation measures contributed to a statistically significant $(p<0.05)$ improvement in the quality of life in patients of the intervention and comparison groups. The most significant positive changes were observed on the scales «Role functioning», «General health», and «Emotional functioning». There was no statistically significant difference between the intervention and comparison groups in terms of all indicators of quality of life evaluated by re-interviewing patients. The outpatient cardiac rehabilitation program using telemedicine technologies demonstrated a positive impact on the quality of life of patients with 
stable coronary heart disease that was compared with the effect of a conventional program that run at the center. The rehabilitation program resulted in significant positive changes in the indicators of physical and mental health that were observed both in the intervention and comparison group. In contrast, no statistically significant changes in all quality of life indicators was found in the comparison group.

Keywords: telecardiac rehabilitation, physical therapy, coronary heart disease, quality of life.

Постановка проблеми. Серцево-судинні захворювання (СС3) $€$ провідною причиною смертності населення в Україні, Європі та усьому світі [26]. Найпоширенішою формою ССЗ та основною причиною втрати здоров'я і скорочення тривалості життя населення $\epsilon$ ішемічна хвороба серця (IXC) [9].

Розвиток кардіореабілітації (КР) $є$ ключовим чинником зниження смертності серед пацієнтів із СС3, зменшення рівня інвалідизації, покращення перебігу захворювання, поліпшення якості життя кардіологічних хворих $[5,19]$.

Однак незважаючи на переконливі докази переваг КР (клас IA) [16], менше половини пацієнтів із IXC беруть участь у програмах КР через ряд соціально-демографрічних фракторів [17].

Найчастіше основними перешкодами для участі пацієнтів у кардіореабілітаційних програмaх називають логістичні фактори [7]. Також дуже важливими $€$ контекстуальні аспекти, наприклад проблеми доступності, механізми скерування пацієнтів на реабілітацію, які залежать від особливостей системи охорони здоров'я в тій чи іншій країні [8].

Згідно з результатами нещодавнього дослідження, Україна належить до країн, в яких КР не доступна для більшості хворих на IXC [23].

Реабілітаційні послуги, які надаються хворим на IXC в Україні, включають медикаментозну реабілітацію, хірургічні втручання за показами, консультування з модифрікації способу життя. Фізичний компонент реабілітації передбачений тільки на стаціонарному етапі лікування, а на амбулаторному етапі, відповідно до існуючої нормативної документації, він не $\epsilon$ обов'язковим $[2,3]$.

Таким чином, обсяг та формат надання реабілітаційних послуг кардіологічним хворим в Україні не дозволяють вирішувати основні завдання КР, які полягають у максимально можливому відновленні самостійності пацієнтів, фрізичної працездатності та якості життя, а також впровадженні заходів вторинної профрілактики, спрямованих на корекцію модифрікованих фракторів ризику [6]. Вирішення всіх цих завдань потребує тривалого реабілітаційного втручання та залучення пацієнтів до програм фрізичних тренувань у рамках амбулаторної КР. Згідно із сучасними рекомендаціями, тривалість таких програм має становити в середньому 12 тиж., а їх вміст повинен базуватися на індивідуальному оцінюванні фізичних, психічних, поведінкових та соціальних факторів [4].

КР із застосуванням телемедичних технологій, або телекардіореабілітація (ТКР), - перспективна модель надання реабілітаційних послуг, що швидко розвивається протягом останніх 10 років та має потенціал до усунення бар'єрів, які перешкоджають участі пацієнтів у програмах КР [11].

TКР передбачає організацію надання однієї чи кількох послуг у рамках програм КР за межами лікувального закладу чи реабілітаційного центру за допомогою пристроїв дистанційного моніторингу та дистанційного спілкування 3 пацієнтами, бажано з використанням сучасних технологій зв'язку, таких як Інтернет або відеоконсультації [13].

Останні систематичні огляди та метааналізи показують, що ТКР може бути ефективною альтернативою традиційній КР з точки зору досягнення функціонального покращення, управління фокторами ризику, без суттєвої різниці у показниках смертності або повторних госпіталізацій $[15,22,24]$.

TКР також може служити високоефективним доповненням традиційних (реалізованих на базі реабілітаційного відділення (центру) програм КР, як продемонстровано у дослідженні Telerehab III [12].

Європейське товариство кардіологів (European Society of Cardiology) та Європейська асоціація превентивної кардіологіï (European Association of Preventive Cardiology) визнають TКР цінним компонентом вторинної серцево-судинної профрілактики [5, 11, 21].

Ще більшої актуальності в усьому світі напрям TKP набув у період пандемії COVID-19 [20]. Однак у науковій літературі не знайдено згадок про впровадження та дослідження ефективності програм ТКР із використанням сучасних інфрормаційних технологій в Україні.

Роботу виконано відповідно до плану науково-дослідної роботи (НДР) Національного університету фрізичного виховання і спорту України (НУФВСУ) на 2016-2020 рр. за темою 4.2 «Організаційні та теоретико-методичні основи фрізичної реабілітації осіб різних нозологічних, 
профресійних та вікових груп» (номер держреєстрації 0116U001609) та відповідно до плану НДР НУФВСУ на 2021-2025 рр. за темою 4.1 «Відновлення функціональних можливостей, діяльності та участі осіб різних нозологічних, професійних та вікових груп засобами фрізичної терапії» (номер держреєстрації 0121U107926).

Мета дослідження - оцінити вплив реабілітаційної програми із застосуванням фрізичних тренувань, що ґрунтується на використанні телемедичних технологій, на якість життя хворих на стабільну ішемічну хворобу серця (CIXC).

Методи дослідження: аналіз медичної документації, статистична обробка даних.

Методи статистичної обробки даних. Математичну обробку числових даних проводили за допомогою методів варіаційної статистики. Аналіз відповідності виду розподілення кількісних показників закону нормального розподілення перевіряли за критерієм Шапіро-Уілка (W). Для кількісних показників, які мали нормальне розподілення, визначали середнє значення $(\bar{x})$ та середньоквадратичне відхилення (S). Для оцінювання значущості різниці між залежними групами використовували критерій Вілкоксона. Для оцінювання значущості різниці між трьома незалежними групами використовували ранговий аналіз варіацій за Краскелом-Уолісом (Kruskel-Wallis ANOVA). Значущість різниці для якісних показників оцінювали за допомогою точного критерію Фішера. Статистично значущими вважалися відмінності, що не перевищували рівня вірогідності p $<0,05$ при заданому числі ступенів свободи. Для математичної обробки числових даних використовували прикладну програму Statistica 10.0.

Результати дослідження та їх обговорення. Дослідження проводили на базі фрілії № 3 Комунального некомерційного підприємства «Консультативно-діагностичний центр Дніпровського району м. Києва». У ньому взяли участь 62 хворих на CIXC, які проходили лікування та спостереження в цьому лікувальному закладі. Критеріями включення у дослідження були: вік до 70 років, діагноз СІХC, відсутність протипоказань до участі у програмі фрізичних тренувань, приналежність до груп низького або помірного ризику, наявність смартфона, вміння користуватися цифровими технологіями.

Критерії виключення: хронічна серцева недостатність I-IV класу за NYHA, нестабільна стенокардія, нестабільний клінічний статус, гострий коронарний синдром в анамнезі протягом останніх 40 днів, черезшкірна ангіопластика протягом останніх двох тижнів, аортокоронарне шунтування протягом останніх трьох місяців, частота сер- цевих скорочень у спокої $\geq 90$ уд/хв, тахіпное $\geq 20$ вдихів за хвилину, симптоматична та/або спричинена фрізичними вправами серцева аритмія чи порушення провідності, гострий міокардит та/або перикардит, клапанна або вроджена вада серця, що вимагає хірургічного лікування, гіпертрофрічна кардіоміопатія, неконтрольована артеріальна гіпертензія, анемія, важкі захворювання дихальної системи, фрізичні вади, пов'язані із серйозними проблемами опорно-рухового апарату або неврологічними проблемами, недавня емболія, тромбофрлебіт, гостре або хронічне запальне захворювання, гострі або хронічні декомпенсовані несерцеві захворювання в стадії декомпенсації (тиреотоксикоз, неконтрольований цукровий діабет), активні злоякісні новоутворення, аневризма аорти, важкі психічні розлади, відмова пацієнта від участі.

Усі учасники дослідження підписали інформовану форму згоди. Дослідження було проведено 3 дотриманням міжнародних принципів Гельсінкської декларації Світової медичної асоціації [1] та відповідно до Закону України «Основи українського законодавства про охорону здоров'я» про етичні норми і правила проведення медичних досліджень за участю людини [27].

Усі учасники дослідження були розподілені на три групи: групу втручання (ГВ), групу порівняння (ГП) та групу контролю (ГК).

Програми амбулаторної реабілітації для пацієнтів ГВ та ГП включали застосування заходів фрізичної терапії, освітньої програми та заходів із корекції модифікованих фракторів ризику. Програми фрізичної терапії для пацієнтів ГВ та ГП будували з урахуванням рекомендацій Європейського товариства кардіологів [16].

Амбулаторна програма фрізичної терапії для ГВ включала в середньому 24 заняття, які проводили три рази на тиждень. Перші вісім занять були контрольованими, їх проводили на базі центру активного дозвілля за місцем проживання пацієнтів, наступні заняття проводилися пацієнтами самостійно в домашніх умовах. Для реалізації програми в домашніх умовах було створено вебсторінку з персоналізованим доступом, через яку пацієнт отримував усю інформацію щодо програми тренувань, індивідуалізовані поради та надавав звіти фрізичному терапевту щодо виконання призначень. За допомогою додатка для смартфонів (Leap Fitness Group), який було встановлено всім пацієнтам на початку дослідження, здійснювали контроль та корекцію рівнів щоденної рухової активності. Спілкування пацієнтів із фрізичним терапевтом проводили регламентовано, раз на тиждень, у фрорматі миттєвих текстових 
повідомлень, за допомогою електронної пошти, відеодзвінків або телефонних розмов - залежно від вподобань пацієнта. У разі виникнення технічних проблем учасники могли отримати підтримку протягом 24 год. Освітня програма для ГВ включала шість індивідуальних навчальних занять із важливих для пацієнта тем, які проводили дистанційно, у вигляді відеоконференцій, а також надання пацієнтам доступу до інформації для самостійного ознайомлення.

Для ГП програма фрізичної терапії та освітня програма були реалізовані на базі центру активного дозвілля за місцем проживання пацієнтів. Кількість сесій фізичної терапії та занять у рамках освітньої програми у ГВ та ГП не відрізнялися.

Пацієнти ГК не брали участі у програмі тривалих фрізичних тренувань та освітній програмі. Реабілітаційні заходи для них включали отримання рекомендацій від лікаря щодо модифрікації фракторів ризику та рухової активності відповідно до Уніфрікованого клінічного протоколу первинної, вторинної (спеціалізованої) та третинної (високоспеціалізованої) медичної допомоги "Стабільна ішемічна хвороба серця» [2].

Оцінювання якості життя всіх учасників проводили на початку дослідження та через два місяці.

Соціодемограсрічні та клінічні дані було отримано під час опитування пацієнтів та за допомогою аналізу медичної документації.

Оцінювання якості життя проводили за допомогою опитувальника SF-36 [25]. 36 пунктів опитувальника згруповані у вісім шкал: фрізичне функціонування, рольове функціонування, тілесний біль, загальне здоров'я, життєздатність, соціальне функціонування, емоційне функціонування і психічне здоров'я. Показники кожної шкали варіюють між 0 і 100, де 100 балів відповідають повному здоров'ю. Для проведення опитування та підрахунку результатів використовували онлайнкалькулятор опитувальника SF-36: https://sites. google.com/site/71microsurgery/home/sf36.

У таблиці 1 наведено базові демографічні та клінічні характеристики учасників дослідження. Як видно з представлених даних, на початковому етапі дослідження між групами не було істотної різниці за основними чинниками, що можуть вплинути на ефрективність реабілітаційних заходів.

Із пацієнтами ГВ було проведено в середньому $23,5 \pm 1,4(\bar{x} \pm$ S) заняття фрізичної терапії, у ГП відповідний показник становив $24,1 \pm 1,2$ заняття.

Протягом проведення дослідження у пацієнтів ГВ та ГП не спостерігали жодних випадків нападів стенокардії чи будь-яких ускладнень під
ТАБЛИЦЯ 1 - Соціодемографічні та клінічні характеристики пацієнтів на початку дослідження, $\mathrm{n}=62$

\begin{tabular}{|l|c|c|c|}
\hline \multicolumn{1}{|c|}{ Показник } & $\begin{array}{c}\text { Група } \\
\text { втручання } \\
\text { (n= 20) }\end{array}$ & $\begin{array}{c}\text { Група } \\
\text { порівняння } \\
\text { (n= 20) }\end{array}$ & $\begin{array}{c}\text { Група } \\
\text { контролю } \\
\text { (n = 22) }\end{array}$ \\
\hline Вік, років $(\bar{x} \pm \mathrm{S})$ & $59,8 \pm 5,9$ & $58,6 \pm 5,8$ & $58,8 \pm 8,4$ \\
\hline Кількість чоловіків, n (\%) & $12(60)$ & $13(65)$ & $12(54,5)$ \\
\hline Кількість курців, n (\%) & $3(15)$ & $4(20)$ & $4(18,2)$ \\
\hline $\begin{array}{l}\text { Кількість осіб, що мають } \\
\text { артеріальну гіпертензію, } \\
\text { n (\%) }\end{array}$ & $10(50)$ & $9(45)$ & $8(36,4)$ \\
\hline $\begin{array}{l}\text { Кількість осіб, що мають } \\
\text { ожиріння, n (\%) }\end{array}$ & $1(5)$ & $2(10)$ & $2(9)$ \\
\hline $\begin{array}{l}\text { Кількість осіб, що мають } \\
\text { цукровий діабет ІІ типу, } \\
\text { п (\%) }\end{array}$ & $0(0)$ & $1(5)$ & $1(4,5)$ \\
\hline
\end{tabular}

час сесій фрізичної терапії; у групі ГВ за весь період реабілітаційного втручання було зафріксовано 16 випадків незначних технічних проблем, які не вплинули на реабілітаційний процес.

У таблиці 2 представлено динаміку якості життя учасників дослідження протягом реалізації програми амбулаторної реабілітації.

Повторне обстеження пацієнтів через два місяці показало, що застосування реабілітаційних заходів сприяло статистично значущому $(p<0,05)$ покращенню якості життя у пацієнтів ГВ та ГП.

Серед показників, що характеризують фрізичний компонент здоров'я, найбільш суттєву позитивну динаміку спостерігали за шкалами «Рольове фрункціонування» та «Загальне здоров'я». Зокрема, у ГВ показник загального здоров'я збільшився з $38,7 \pm 11,0$ до $51,3 \pm 6,8$ бала $(p<0,05)$, а в ГП - $339,5 \pm 11,6$ до $52,3 \pm 4,7$ бала $(p<0,05)$.

Щодо складових психічного здоров'я, то найбільше поліпшення було зафріксовано за шкалою «Емоційне функціонування»: спостерігали покращення цього показника з $42,1 \pm 15,1$ до $61,4 \pm 12,5$ бала $(p<0,05)$ та з 41,7 $\pm 14,8$ до $61,7 \pm 12,2$ бала $(\mathrm{p}<0,05)$ у ГВ і ГП відповідно. При цьому не було виявлено статистично значущої різниці між ГВ та ГП за всіма показниками якості життя, отриманими при повторному опитуванні пацієнтів.

Аналіз результатів, що були отримані для ГК, показав відсутність статистично значущої різниці між початковими та кінцевими показниками якості життя у пацієнтів, які не були включені до програм фрізичної терапії.

Таким чином, отримані дані підтверджують положення про користь фрізичного компонента КР та його позитивний вплив на якість життя осіб, хворих на IXC [6]. 
ТАБЛИЦЯ 2 - Динаміка якості життя хворих на стабільну ішемічну хворобу серця під впливом амбулаторної реабілітації, $\mathrm{n}=62$

\begin{tabular}{|c|c|c|c|c|c|c|}
\hline \multirow{3}{*}{$\begin{array}{c}\text { Показник якості життя (бал) } \\
\text { за шкалою SF-36 }\end{array}$} & \multicolumn{6}{|c|}{ Значення показника, $\bar{x} \pm S$} \\
\hline & \multicolumn{2}{|c|}{ група втручання (n = 20) } & \multicolumn{2}{|c|}{ група порівняння ( $n=20)$} & \multicolumn{2}{|c|}{ група контролю (n = 22) } \\
\hline & $\begin{array}{c}\text { на початку } \\
\text { дослідження }\end{array}$ & $\begin{array}{l}\text { через } \\
2 \text { міс. }\end{array}$ & $\begin{array}{c}\text { на початку } \\
\text { дослідження }\end{array}$ & $\begin{array}{l}\text { через } \\
2 \text { міс. }\end{array}$ & $\begin{array}{c}\text { на початку } \\
\text { дослідження }\end{array}$ & $\begin{array}{l}\text { через } \\
2 \text { міс. }\end{array}$ \\
\hline Фізичне фуннкціонування & $43,9 \pm 7,9$ & $50,9 \pm 7,2^{*}$ & $42,0 \pm 8,5$ & $49,5 \pm 5,6^{*}$ & $45,2 \pm 8,1$ & $44,3 \pm 7,8 \#^{\wedge}$ \\
\hline Рольове функціонування & $36,8 \pm 15,3$ & $46,6 \pm 8,3^{*}$ & $40,0 \pm 12,6$ & $48,8 \pm 5,6^{*}$ & $36,9 \pm 12,8$ & $41,7 \pm 12,1^{\wedge}$ \\
\hline Біль & $63,9 \pm 8,9$ & $69,6 \pm 8,1^{*}$ & $64,9 \pm 8,5$ & $73,6 \pm 5,9^{*}$ & $61,7 \pm 8,7$ & $64,7 \pm 8,6 \#^{\wedge}$ \\
\hline Загальне здоров'я & $38,7 \pm 11,0$ & $51,3 \pm 6,8^{*}$ & $39,5 \pm 11,6$ & $52,3 \pm 4,7^{*}$ & $41,7 \pm 7,9$ & $41,4 \pm 8,9 \#^{\wedge}$ \\
\hline Життєздатність & $40,0 \pm 8,8$ & $47,8 \pm 4,5^{*}$ & $41,5 \pm 9,5$ & $49,0 \pm 5,5^{\star}$ & $42,1 \pm 6,6$ & $43,6 \pm 7,8 \#^{\wedge}$ \\
\hline Соціальне функціонування & $63,2 \pm 8,8$ & $71,1 \pm 7,3^{*}$ & $62,5 \pm 9,1$ & $70,6 \pm 7,3^{*}$ & $61,9 \pm 9,2$ & $64,9 \pm 7,5 \#^{\wedge}$ \\
\hline Емоційне функціонування & $42,1 \pm 15,1$ & $61,4 \pm 12,5^{*}$ & $41,7 \pm 14,8$ & $61,7 \pm 12,2^{*}$ & $42,9 \pm 15,4$ & $41,8 \pm 15,1 \#^{\wedge}$ \\
\hline Психічне здоров'я & $45,1 \pm 8,2$ & $55,5 \pm 5,3^{*}$ & $47,2 \pm 6,8$ & $54,9 \pm 3,0^{*}$ & $44,8 \pm 8,1$ & $46,4 \pm 6,2 \#^{\wedge}$ \\
\hline
\end{tabular}

Примітки: *- різниця статистично значуща між показником «на початку дослідження» та «через 2 міс.» при р < 0,05; \# - різниця статистично значуща між показниками ГВ та ГК при $\mathrm{p}<0,05$; ^ $^{-}$різниця статистично значуща між показниками ГП та ГК при $\mathrm{p}<0,05$.

У цьому дослідженні також було підтверджено дані інших авторів щодо ефективності ТКР порівняно з традиційними програмами КР. Зокрема, отримані результати узгоджуються з даними М. Cartwright et al. [10], які також спостерігали покращення якості життя як у групі ТКР, так і в групі пацієнтів, що проходили програму на базі реабілітаційного центру.

Отримані дані доповнюють результати інших досліджень щодо впливу програм ТКР на якість життя хворих на IXC. Так, згідно з даними J. J. Kraal et al. [18], програма ТКР мала позитивний вплив переважно на фізичний компонент здоров'я: автори зафріксували покращення на $13 \%$ в оцінці фрізичного компонента та на $4 \%$ в оцінці ментальної складової. Однак у своєму дослідженні для оцінювання якості життя автори використовували інший опитувальник (MacNew questionnaire), чим може пояснюватися різниця в отриманих результатах.

Таким чином, зважаючи на те, що ефективність кардіореабілітаційних програм у цілому не залежить від обраного формату (ТКР чи традиційна КР), ТКР може бути кращою альтернативою для залучення пацієнтів, які живуть далеко від реабілітаційних установ чи з інших причин не можуть відвідувати реабілітаційні заняття у форматі «віч-на-віч».

\section{Література}

1. Закон України. Основи законодавства України про охорону здоров'я (2802 XII) [The law of Ukraine. Fundamentals of the Ukrainian Legislation on Health Care (2802-XII)] [Electronic resource]. - 1993; 4: 19. Access mode: https://zakon.rada.gov.ua/laws/show/2801-12\#

2. Міністерство здоров'я України. Уніфікований клінічний протокол первинної, вторинної (спеціалізованої) та третинної (високоспеціалізованої) медичної допомоги (УКПМД) «Стабільна ішемічна хвороба серця» [Ministry of Health of Ukraine. Unified clinical protocol of primary, secondary
Обмеження. Слід зазначити, що хоча результати, отримані в даному дослідженні, $є$ оптимістичними 3 точки зору використання ТКР як можливої альтернативи традиційним програмам на базі реабілітаційного центру, їх потрібно інтерпретувати з урахуванням таких обмежень:

- малі вибірки учасників дослідження;

- у дослідження були включені тільки пацієнти груп низького та помірного ризику;

- невелика тривалість спостереження;

- дослідження не засліплене.

Висновки. Амбулаторна програма КР із застосуванням телемедичних технологій продемонструвала позитивний вплив на якість життя хворих на CIXC, порівнюваний із ефектом програми, реалізованої на базі центру.

Під впливом реабілітаційної програми у ГВ та ГП спостерігали суттєву позитивну динаміку показників, що характеризують як фрізичний, так і психічний компоненти здоров'я, тоді як у ГК статистично значущих змін за всіма показниками якості життя виявлено не було.

Перспективи подальших досліджень полягають у розробленні технології ТКР для хворих на IXC, що дозволить підвищити рівень залученості хворих на CIXC до програм фрізичної терапії на амбулаторному етапі.

(specialized) and tertiary (highly specialized) medical care (UCPMC) «Stable coronary heart disease»]. 2016. $75 p$.

3. Національна служба здоров'я України. Пакети медичних послуг Зміст та підхід до контрактування закладів охорони здоров'я [National Health Service of Ukraine. Medical service packages. Content and approach to contracting health care facilities]. 2020.67 p.

4. Ambrosetti M, Abreu A, Corrà U, Davos $\mathrm{CH}$, Hansen D, Frederix I et al. Secondary prevention through comprehensive cardiovascular rehabilitation: 
From knowledge to implementation. 2020 update. A position paper from the Secondary Prevention and Rehabilitation Section of the European Association of Preventive Cardiology 2020; Eur J Prev Cardiol, 30, 20474873-20913379. doi: 10.1177/2047487320913379. Epub ahead of print. PMID: 32223332

5. Anderson L, Sharp GA, Norton RJ, Dalal H, Dean SG, Jolly K et al. Home-based versus centre-based cardiac rehabilitation. Cochrane Database Syst Rev. 2017; 6(6):130. doi: 10.1002/14651858.CD007130.pub4.

6. Anderson L, Thompson DR, Oldridge N, Zwisler AD, Rees K, Martin N, \& Taylor RS. Exercise-based cardiac rehabilitation for coronary heart disease. Cochrane Database Syst Rev. 2016; 1. CD001800. doi: 10.1002/14651858. CD001800.pub3.

7. Bakhshayeh S, Sarbaz M, Kimiafar K, Vakilian F, \& Eslami S. Barriers to participation in center-based cardiac rehabilitation programs and patients attitude toward home-based cardiac rehabilitation programs. Physiother Theory Pract. 2021; 37(1): 158-68. doi: 10.1080/09593985.2019.1620388.

8. Borg S, Öberg B, \& Leosdottir M. Factors associated with nonattendance at exercise-based cardiac rehabilitation. BMC Sports Sci Med Rehabil. 2019; 26:11-3

9. Case BC, \& Waksman R. Coronary Heart Disease: Have We Reached a Plateau in Primary Prevention? J Am Heart Assoc. 2020;7;9(7): e04963. doi: 10.1161/JAHA.120.016034.

10. Cartwright M, Hirani S, Rixon L, Beynon M, Doll H, Bower P, \& Rogers A. Effect of telehealth on quality of life and psychological outcomes over 12 months (Whole Systems Demonstrator telehealth questionnaire study): Nested study of patient reported outcomes in a pragmatic, cluster randomised controlled trial. BMJ, 346, f653.

11. Frederix I, Caiani EG, Dendale P, Anker S, Bax J, Böhm A, et al. ESC e-Cardiology Working Group position paper: overcoming challenges in digital health implementation in cardiovascularmedicine. Eur J Prev Cardiol. 2019; 26(11), 1166-77. doi: 10.1177/2047487319832394.

12. Frederix I, Hansen D, Coninx $K$, Vandervoort $P$, Vandijck $D$, Hens $\mathrm{N}$ et al. Effect of comprehensive cardiac telerehabilitation on oneyear cardiovascular rehospitalization rate, medical costs and quality of life: a cost-effectiveness analysis. Eur J Prev Cardiol. 2016;23(7):674-82. doi: $10.1177 / 2047487315602257$.

13. Frederix I, Vanhees L, Dendale P, \& Goetschalckx K. A review of telerehabilitation for cardiac patients. J Telemed Telecare. 2015; 21(1):45-53. doi: 10.1177/1357633X14562732.

14. Global Burden of Cardiovascular Diseases and Risk Factors, 19902019: Update From the GBD 2019. JACC. 2019; 76(25). Retrieved from https:// www.jacc.org/doi/10.1016/j.jacc.2020.11.010
15. Huang K, Liu W, He D, Huang B, Xiao D, Peng Y, et al. Telehealth interventions versus center-based cardiac rehabilitation of coronary artery disease: a systematic review and meta-analysis. Eur J Prev Cardiol, 22, 959 71. doi: $10.1177 / 2047487314561168$.

16. Knuuti J, Wijns W, Saraste A, Capodanno D, Barbato E, FunckBrentano C et al. 2019 ESC Guidelines for the diagnosis and management of chronic coronary syndromes. Eur Heart J. 2020; 41(3): 407-77. doi: 10.1093/ eurheartj/ehz425.

17. Kotseva K, Wood D, De Bacquer D, \& Investigators E. Determinants of participation and risk factor control according to attendance in cardiac rehabilitation programmes in coronary patients in Europe: EUROASPIRE IV survey. Eur J Prev Cardiol. 2018; 25(12): 1242-51.

18. Kraal JJ, Peek N. Effects of home-based training with telemonitoring guidancein low to moderate risk patients entering cardiac rehabilitation: Short-term results of the FIT@Home study. Eur J PrevCardiol. 2014; 21, 26-31.

19. Long L, Mordi I, Bridges C, Sagar VA, Davies EJ, Coats AJ et al. Exercise-based cardiac rehabilitation for adults with heart failure. Cochrane Database Syst Rev, 29, 1(1):CD003331. doi: 10.1002/14651858.

20. Moulson N, Bewick D, Selway T, Harris J, Suskin N, Oh P et al. Cardiac Rehabilitation During the COVID-19 Era: Guidance on Implementing Virtual Care. Can J Cardiol. 2020; 36(8): 1317-21. doi: 10.1016/j.cjca.2020.06.006.

21. Piepoli MF, Hoes AW, Agewall S, Albus C, Brotons C, Binno S. European guidelines on cardiovascular disease prevention in clinical practice. EurHeart J. 2016; 37(29): 2315-81.

22. Rawstorn JC, GantN, Direito A, Beckmann C, \& Maddison R. Telehealth exercise-based cardiac rehabilitation: a systematic review and metaanalysis. Heart. 2016; 102(15): 1183-92. doi: 10.1136/heartjnl-2015-308966.

23. Turk-Adawi K, Supervia M, Lopez-Jimenez F, Pesah E, Ding R, Britto RR et al. Cardiac Rehabilitation Availability and Density around the Globe Eclinical Medicine. 2019; 3(13): 31-45. doi: 10.1016/j.eclinm.2019.06.007.

24. Veen EV, Bovendeert JFM, Backx FJG. \& Huisstede BMA. E-coaching new future for cardiac rehabilitation? A systematic review. Patient Educ Couns 100(12): 2218-30. doi: 10.1016/j.pec.2017.04.017.

25. Ware JE, \& Sherbourne CD. The MOS 36-item short-form health survey (SF-36): I. Formatual framework and item selection. Med. Care. 1992; 30: 473-83.

26. WHO. Cardiovascular diseases. 2021. Retrieved from https://www. who.int/news-room/fact-sheets/detail/cardiovascular-diseases-(cvds).

27. World Medical Association. World Medical Association Declaration of Helsinki: ethical principles for medical research involving human subjects. JAMA. 2013; 310(20): 2191-4. doi: 10.1001/jama.2013.281053.

Надійшла 21.09.2021 